\title{
Pengaruh Dosis Pupuk Majemuk NPK + Zn terhadap Pertumbuhan, Produksi, dan Serapan Zn Padi Sawah di Inceptisol, Kebumen
}

\author{
DOI 10.18196/pt.2016.062.101-106
}

\author{
Latifah Arifiyatun, Azwar Maas, Sri Nuryani Hidayah Utami \\ Jurusan Ilmu Tanah, Fakultas Pertanian, Universitas Gadjah Mada, \\ Jl. Flora, Bulaksumur, Depok, Sleman, Yogyakarta 55281, Indonesia, Telp./fax.: (0274) 563062, \\ e-mail: latifah.arifiyatun@yahoo.com
}

\begin{abstract}
ABSTRAK
Penelitian ini bertujuan untuk mengetahui formula Zn optimum yang dapat ditambahkan pada pupuk NPK dosis 300 kg/ha dan tambahan Urea 200 kg/ ha, pupuk organik 500 kg/ha, pengaruhnya terhadap serapan hara Zn serta produksi padi. Budidaya padi umumnya diberikan pupuk makro sintetis tanpa pengembalian residu tanaman dan bahan organik sebagai pembenah tanah sekaligus penyedia hara mikro. Selain itu, akumulasi P dalam tanah menekan ketersediaan Zn, pada pH netral hingga alkalis Zn tidak tersedia dan relatif mobile, saat tanah tergenang Zn mengendap, dan tidak pernah dipupuk hara mikro Zn. Lahan intensif untuk pembuatan batubata, genting, terindikasi mengalami pengurasan Zn yang nampak gejala daun tanaman padi berkurang ketegarannya, berwarna hijau pucat 2-4 hari setelah digenangi kemudian krotik dan mengering. Penelitian inovasi pupuk mikro dilakukan pada bulan Juli 2014 hingga Januari 2015, di rumah kaca Fakultas Pertanian, Universitas Gadjah Mada dengan menggunakan media tanah InseptisolKebumen, sebanyak 10 perlakuan. dosis NPK Plus Zn dengan rentang kadar Zn 0,25\% dari 0\% hingga 2\% Zn diulang sebanyak 3 kali menggunakan Rancangan Acak Lengkap (RAL). Hasil penelitian menunjukkan bahwa tanah yang diberikan tambahan 1,75\% Zn memiliki kandungan Zn tersedia tertinggi yaitu 0,16 mg/kg dengan kandungan Zn jaringan trubus sebesar 68,38 mg/kg, sedangkan pada perlakuan kontrol mempunyai nilai terendah yaitu 0,07 mg/kg dengan kandungan Zn jaringan trubus sebesar $47,85 \mathrm{mg} / \mathrm{kg}$. Tidak terlihat peningkatan hasil disebabkan oleh pemberian tambahan Zn sampai takaran 2\% dari pupuk NPK plus Zn yang diberikan, tetapi kecenderungan takaran 1,75\% Zn memberikan hasil produksi tertinggi dengan ektrapolasi yang cukup ke total populasi mencapai 9,96 ton/ha sedangkan pada kontrol 3,45 ton/ha.

Kata kunci : Lahan sawah intensif, Padi sawah, Serapan Zn, Produksi padi
\end{abstract}

\begin{abstract}
The study was conducted to identify the optimum Zn formula that could be added to dose $300 \mathrm{~kg} / \mathrm{ha}$ NPK fertilizer with the additional $200 \mathrm{~kg} / \mathrm{ha}$ urea, organic fertilizer $500 \mathrm{~kg} / \mathrm{ha}$ and its implication on Zn nutrient uptake and paddy production. Generally, paddy cultivation practices applied macro-synthetic fertilizers without returning crop residues and organic materials as a soil conditioner as well as to provide micronutrients. In addition, the accumulation of $P$ in the soil is pressing the availability of $Z n$, at neutral $\mathrm{pH}$ to alkaline $\mathrm{Zn}$ is not available and relatively mobile, when the soil is waterlogged $\mathrm{Zn}$ would be settled, and usually Zn is never be fertilized. Moreover, the land is intensively used for the manufacture of bricks and tiles indicate experiencing Zn depletion will cause symptoms on leaves of rice plants reduced toughness, pale green after 2-4 days later on flooded would be krotik and dried up. The research of fertilization innovation on micronutrients were conducted on July 2014 - January 2015 in Green House Agriculture Faculty, the University of Gajah Mada where the planting media of this research was Inceptisol which taken from Kebumen. The treatment were 10 treatments with a dose of NPK Plus Zn $0.25 \%$ Zn content ranges from 0\% to 2\% Zn repeated 3 times using a complete randomized design (CRD). The results showed that the land was given an additional $1.75 \%$ Zn has provided the highest Zn content of $0.16 \mathrm{mg} / \mathrm{kg}$ with a content of Trubus tissue's $Z n 68,38 \mathrm{mg} / \mathrm{kg}$. Whereas in the control treatment had the lowest score is $0.07 \mathrm{mg} / \mathrm{kg}$ with Zn content of trubus tissue was $47.85 \mathrm{mg} / \mathrm{kg}$. Not seen an increase in yield due to the additional provision of $2 \% \mathrm{Zn}$ to the dose of NPK fertilizer plus Zn were given, but the tendency dose of $1.75 \%$ Zn gives the highest production yield with and extrapolated enough to the total population reached 9.96 tons/ha while in control was only 3.45 tons/ha.
\end{abstract}

Keywords: Intensive rice land, Rice cultivation, Zn uptake, Rice production

\section{PENDAHULUAN}

Penggunaan pupuk yang berlebihan selain boros juga dapat berdampak buruk bagi lingkungan, sehingga pemupukan berimbang spesifik lokasi diarahkan menggunakan pupuk majemuk dengan berbagai formula, yang bertujuan agar tidak terjadi inefisiensi unsur hara. Berdasarkan hasil penelitian Yulnafatmawita et al. (2014) pada tanah sawah memiliki kandungan hara makro $\mathrm{N}$ dan Ca sedangkan hara mikro Mn dan Zn sangat rendah, yang disebabkan oleh pemupukan yang tidak seimbang antara unsur hara makro dan mikro, tanpa adanya pengembalian residu tanaman, maka menyebabkan ketimpangan jemuk $\mathrm{NPK}+2 \% \mathrm{Zn}$. Masing-masing perlakuan di- 
ulang sebanyak 3 (tiga) kali. Pupuk Organik 500 $\mathrm{kg} /$ ha diberikan awal sebelum tanam, Urea 200 $\mathrm{kg} /$ ha diberikan 3 tahap saat 7 HST (1/2 dosis), 21 HST (1/4 dosis), 35 HST (1/4 dosis), NPK (15-15-15) plus Zn $300 \mathrm{~kg} / \mathrm{ha}$ diberikan 2 tahap saat 7 HST ( $1 / 2$ dosis), 21 HST ( $1 / 2$ dosis). Pengamatan agronomi di lapangan dilakukan pada 104 HST, meliputi tinggi tanaman dan jumlah anakan produktif padi.

\section{Analisis Tanah dan Jaringan Tanaman}

Semua analisis tanah menggunakan metode yang dikembangankan Balittan (2009) yaituanalisis tanah meliputi $\mathrm{pH}\left(\mathrm{H}_{2} \mathrm{O}\right)$ dengan metode elektrometri, C-Organik tanah dengan metode Walkey and Black, N-total tanah dengan metode Kjedahl, kapasitas pertukaran kation (KPK) dengan ekstrak $\mathrm{NH}_{4} \mathrm{Oac} \mathrm{pH} 7,0$, unsur P tersedia dengan metode Olsen (ekstrak $\mathrm{NaHCO}_{3} \mathrm{pH} 8,5$ ) untuk tanah ber-pH $>5,5$. Unsur $\mathrm{K}$ tersedia dengan ekstrak $\mathrm{NH}_{4} \mathrm{Oac} \mathrm{pH} 7,0$, unsur $\mathrm{Zn}$ tersedia dengan ekstrak DTPA. Analisis jaringan tanaman padi meliputi Serapan unsur N, P, K, dan Zn dengan metode destruksi basah, kemudian dihitung serapan haranya.

Rumus serapan hara $=\mathrm{BK}$ (bobot kering) $\mathrm{x} \%$ konsentrasi hara pada jaringan tanaman

\section{Analisis Data}

Rancangan percobaan yang digunakan adalah Rancangan Acak Lengkap (RAL), dengan perlakuan pemberian pupuk Organik, Urea, NPK + Zn pada berbagai dosis. Data hasil analisis yang telah diperoleh akan diinterprestasikan dalam bentuk tabel dan atau histogram.

\section{HASIL DAN PEMBAHASAN}

Karakterisasi Tanah Awal Sebelum Perlakuan

Dari percobaan yang dilakukan diperoleh keterangan status hara awal dalam tanah yang disajikan pada tabel 1 .
Tabel 1. Hasil Pengamatan Analisis Tanah Awal Sebelum Perlakuan

\begin{tabular}{lccc}
\hline \multicolumn{1}{c}{ Jenis Analisis } & Satuan & Nilai & Harkat \\
\hline $\mathrm{pH}\left(\mathrm{H}_{2} \mathrm{O}\right)$ & - & 7,05 & Agak Alkalis \\
$\mathrm{C}-$ Organik & $\%(\mathrm{~b} / \mathrm{b})$ & 2,43 & Sedang \\
Bahan organik & $\%(\mathrm{~b} / \mathrm{b})$ & 4,19 & Sedang \\
$\mathrm{N}$-total & $\%(\mathrm{~b} / \mathrm{b})$ & 0,11 & Rendah \\
$\mathrm{P}_{2} \mathrm{O}_{5}$ tersedia & $\mathrm{mg} / \mathrm{kg}$ & 5,71 & Rendah \\
$\mathrm{K}$ tersedia & $\mathrm{me} / 100 \mathrm{~g}$ & 0,26 & Rendah \\
Zn tersedia & $\mathrm{ppm}$ & 0,09 & Rendah \\
Kapasitas Pertukaran Kation & $\mathrm{cmol}(+) / \mathrm{kg}$ & 22.60 & Sedang \\
Nisbah C/N & - & 22.09 & Tinggi \\
\hline
\end{tabular}

Keterangan : Pengharkatan menurut Balittan (2009), b/b = berat per berat

Hasil analisis sifat kimia tanah awal pada tanah memiliki nilai $\mathrm{pH} \mathrm{\textrm {H } _ { 2 }} \mathrm{O} 7,05$ dengan kandungan C-organik tanah sebesar 2,43\% berharkat sedang. Pada pH tinggi maka ketersediaan $\mathrm{Zn}$ rendah karena terhidroksilasi menjadi mengendap tidak tersedia bagi taanaman. Besarnya nilai KPK adalah 22,60 cmol (+)/ kg berharkat sedang. Kadar $\mathrm{N}$ total tanah $(0,11 \%)$, $\mathrm{P}_{2} \mathrm{O}_{5}(5,71 \mathrm{mg} / \mathrm{kg}), \mathrm{K}(0,26 \mathrm{me} / 100 \mathrm{~g})$ berharkat rendah. Unsur Zn dalam tanah rendah sebesar 0,09 mg/ kg, diduga akibat intensif digunakan tanpa pemberian pupuk organik, unsur mikro, dan tidak ada pengembalian residu tanaman, sehingga unsur hara terutama Zn terkuras dalam tanah. Perlakuan pemberian tambahan unsur $\mathrm{Zn}$ dalam pupuk diharapkan mampu meningkatkan pertumbuhan dan produksi padi.

\section{Pertumbuhan Tanaman Padi}

Pertumbuhan tanaman dikendalikan oleh faktor pertumbuhan, yaitu faktor genetik dan faktor lingkungan. Setiap varietas tanaman memiliki kemampuan berbeda dalam hal memanfaatkan sarana tumbuh sehingga mempengaruhi potensi hasil tanaman.

Pada penelitian ini terlihat perbedaan yang nyata antara tanaman kontrol $(95,8 \mathrm{~cm})$ dengan tanaman yang diberikan pupuk NPK + Zn 1\% 
(108,7 cm). Perlakuan pemupukan NPK + Zn dengan dosis yang berbeda memberikan nilai yang berbeda dan relatif lebih tinggi dibandingkan kontrol. Namun secara umum pada perlakuan pemupukan tidak menunjukan perbedaan yang mencolok pada tinggi tanaman.

Tabel 2. Pengaruh Dosis Pemupukan NPK + Zn terhadap Pertumbuhan Padi

\begin{tabular}{lccc}
\hline Perlakuan & $\begin{array}{c}\text { Tinggi Tanaman } \\
(\mathrm{cm})\end{array}$ & $\begin{array}{c}\text { Jumlah Anakan } \\
\text { Produktif }\end{array}$ & $\begin{array}{c}\text { Berat Trubus } \\
\text { (gram/tanaman) }\end{array}$ \\
\hline Kontrol & $95,8 \mathrm{~b}$ & $13 \mathrm{~b}$ & $40,74 \mathrm{~b}$ \\
$\mathrm{NPK}$ & $98,5 \mathrm{ab}$ & $18 \mathrm{a}$ & $69,26 \mathrm{a}$ \\
$\mathrm{NPK}+0.25 \% \mathrm{Zn}$ & $96,9 \mathrm{ab}$ & $19 \mathrm{a}$ & $73,64 \mathrm{a}$ \\
$\mathrm{NPK}+0.50 \% \mathrm{Zn}$ & $103,1 \mathrm{ab}$ & $18 \mathrm{a}$ & $73,27 \mathrm{a}$ \\
$\mathrm{NPK}+0.75 \% \mathrm{Zn}$ & $100,6 \mathrm{ab}$ & $22 \mathrm{a}$ & $69,15 \mathrm{a}$ \\
$\mathrm{NPK}+1 \% \mathrm{Zn}$ & $108,7 \mathrm{a}$ & $18 \mathrm{a}$ & $66,75 \mathrm{a}$ \\
$\mathrm{NPK}+1.25 \% \mathrm{Zn}$ & $91,2 \mathrm{ab}$ & $22 \mathrm{a}$ & $49,23 \mathrm{~b}$ \\
$\mathrm{NPK}+1.50 \% \mathrm{Zn}$ & $104,4 \mathrm{ab}$ & $19 \mathrm{a}$ & $75,62 \mathrm{a}$ \\
$\mathrm{NPK}+1.75 \% \mathrm{Zn}$ & $103,9 \mathrm{ab}$ & $22 \mathrm{a}$ & $84,23 \mathrm{a}$ \\
$\mathrm{NPK}+2 \% \mathrm{Zn}$ & $100,8 \mathrm{ab}$ & $19 \mathrm{a}$ & $70,73 \mathrm{a}$ \\
\hline
\end{tabular}

Keterangan: Angka yang diikuti oleh huruf yang sama menunjukkan hasil tidak berbeda nyata antar perlakuan dengan uji DMRT 5\%.

Pada penelitian ini terlihat perbedaan yang nyata antara tanaman kontrol $(95,8 \mathrm{~cm})$ dengan tanaman yang diberikan pupuk NPK + Zn 1\% (108,7 cm). Perlakuan pemupukan NPK + Zn dengan dosis yang berbeda memberikan nilai yang berbeda dan relatif lebih tinggi dibandingkan kontrol. Namun secara umum pada perlakuan pemupukan tidak menunjukan perbedaan yang mencolok pada tinggi tanaman.

Tanaman kontrol memiliki anakan produktif paling sedikit yaitu 13 batang dibandingkan pada perlakuan pemberian pupuk, pada pemberian pupuk kadar Zn 0,75\%, 1,25\%, dan 1,75\% memiliki jumlah anakan tertinggi yaitu 22 buah. Perbedaan ini terjadi akibat perbedaan asupan hara tanaman yang sangat mempengaruhi pertumbuhan dan produksi padi. Hal ini sesuai dengan pendapat Setyamidjaja (1996), bahwa setiap unsur hara mempunyai fungsi tersendiri dan dapat mempengaruhi proses tertentu di dalam pertumbuhan dan perkembangan tanaman, jika terdapat kekurangan atau berlebihan unsur hara, maka tanaman akan menunjukkan gejala pertumbuhan yang tidak optimal.

Hasil analisis ragam menunjukkan bahwa bobot trubus basah tanaman berbeda nyata jika dibandingkan dengan kontrol. Keberadaan pupuk NPK + Zn semakin meningkatkan pertumbuhan tanaman padi dan terlihat dari bobot trubus padi. Pada perlakuan pemupukan NPK + Zn 1,75\% memiliki bobot trubus basah tertinggi mencapai 84,23 gram/tanaman. Jika unsur hara yang dibutuhkan tanaman tersedia dalam jumlah yang cukup, maka hasil metabolisme seperti sintesis biomolekul akan meningkat, sehingga pertambahan volume dan bobot trubus meningkat. Sebaliknya tanpa pemberian pupuk, terutama pada tanah yang kurang subur menyebabkan proses sintesis biomolekul terganggu seperti terlihat pada kontrol yang memiliki bobot trubus basah paling rendah jika dibandingkan dengan perlakuaan lain yaitu sebesar 40,74 gram/tanaman. Dari tabel di atas juga dapat dilihat bahwa pada bobot trubus basah pada semua perlakuan penambahan pupuk relatif sama dan tidak berbeda nyata, pada penambah dosis $1,75 \% \mathrm{Zn}$ cenderung paling tinggi meningkatkan berat segar tanaman.

\section{Status Hara Tanah Setelah Panen}

Hasil uji sidik ragam dengan tingkat signifikasi $5 \%$ pada berbagai perlakuan terhadap $\mathrm{N}$ total di dalam tanah menunjukkan ada beda nyata antar perlakuan pemberian pupuk dengan kontrol, namun pada perlakuan antar pemberian $\mathrm{NPK}+$ Zn berbagai dosis tidak menunjukan perbedaan yang nyata. Rendahnya kadar hara dalam tanah diduga sebagai salah satu kendala produksi. Kandungan nitrogen setelah panen pada 
kontrol $(0,12 \%)$, menunjukan nilai yang paling rendah dibandingkan perlakuan lain. Begitu juga pada kandungan $\mathrm{P}$ tersedia, $\mathrm{K}$ tersedia di dalam tanah menunjukkan tidak ada beda nyata antar perlakuan pemberian pupuk dengan kontrol, namun pada kontrol menunjukan nilai paling rendah yaitu 3,09 ppm dan 0,22 me\%.

Tabel 3. Pengaruh Dosis Pemupukan NPK $+Z n$ terhadap N total, P, K dan Zn Tersedia

\begin{tabular}{lcccc}
\hline Perlakuan & $\begin{array}{c}\text { N Total } \\
(\%)\end{array}$ & $\begin{array}{c}\text { P Tersedia } \\
(\mathrm{ppm})\end{array}$ & $\begin{array}{c}\text { K Tersedia } \\
(\mathrm{me} \%)\end{array}$ & $\begin{array}{c}\text { Zn Tersedia } \\
(\mathrm{mg} / \mathrm{kg})\end{array}$ \\
\hline Kontrol & $0.12 \mathrm{e}$ & $3,09 \mathrm{a}$ & $0,22 \mathrm{a}$ & $0,07 \mathrm{~b}$ \\
$\mathrm{NPK}$ & $0.15 \mathrm{~d}$ & $4,29 \mathrm{a}$ & $0,25 \mathrm{a}$ & $0,08 \mathrm{~b}$ \\
$\mathrm{NPK}+0.25 \% \mathrm{Zn}$ & $0.15 \mathrm{~cd}$ & $5,07 \mathrm{a}$ & $0,25 \mathrm{a}$ & $0,10 \mathrm{ab}$ \\
$\mathrm{NPK}+0.50 \% \mathrm{Zn}$ & $0.16 \mathrm{~cd}$ & $3,56 \mathrm{a}$ & $0,25 \mathrm{a}$ & $0,10 \mathrm{ab}$ \\
$\mathrm{NPK}+0.75 \% \mathrm{Zn}$ & $0.17 \mathrm{a}$ & $3,38 \mathrm{a}$ & $0,24 \mathrm{a}$ & $0,10 \mathrm{ab}$ \\
$\mathrm{NPK}+1 \% \mathrm{Zn}$ & $0.17 \mathrm{a}$ & $3,45 \mathrm{a}$ & $0,23 \mathrm{a}$ & $0,10 \mathrm{ab}$ \\
$\mathrm{NPK}+1.25 \% \mathrm{Zn}$ & $0.16 \mathrm{bcd}$ & $4,51 \mathrm{a}$ & $0,25 \mathrm{a}$ & $0,10 \mathrm{ab}$ \\
$\mathrm{NPK}+1.50 \% \mathrm{Zn}$ & $0.17 \mathrm{a}$ & $3,66 \mathrm{a}$ & $0,25 \mathrm{a}$ & $0,11 \mathrm{ab}$ \\
$\mathrm{NPK}+1.75 \% \mathrm{Zn}$ & $0.16 \mathrm{abc}$ & $3,90 \mathrm{a}$ & $0,24 \mathrm{a}$ & $0,16 \mathrm{a}$ \\
$\mathrm{NPK}+2 \% \mathrm{Zn}$ & $0.16 \mathrm{ab}$ & $3,90 \mathrm{a}$ & $0,25 \mathrm{a}$ & $0,13 \mathrm{ab}$ \\
\hline
\end{tabular}

Keterangan: Angka yang diikuti oleh huruf yang sama menunjukkan hasil tidak berbeda nyata antar perlakuan dengan uji DMRT $5 \%$.

Hasil uji sidik ragam dengan tingkat signifikasi $5 \%$ pada berbagai perlakuan terhadap kandungan status hara $\mathrm{Zn}$ setelah panen di dalam tanah menunjukkan tidak ada beda nyata antara perlakuan pemberian pupuk NPK + Zn dengan kontrol, kecuali pada tambahan 1,75\% Zn dibandingkan kontrol. Ketidakseimbangan hara yang kahat Zn diduga karena status Zn- DTPA tanah lebih kecil dari batas kritis (1 ppm Zn), sehingga Zn menjadi faktor pembatas pertumbuhan. Sangat dimungkinkan nilai Zn-DTPA lebih besar dari batas kritis, tetapi $\mathrm{Zn}$ yang diserap tanaman sangat sedikit dan aktivitas $\mathrm{Zn}$ ditentukan oleh $\mathrm{pH}$ tanah, redoks tanah (Eh), dan kandungan residu $\mathrm{P}$ tanah tinggi (Al-Jabri dan Soepartini 1995). Selain penambahan kadar Zn dalam pupuk NPK, penambahan bahan organik mampu menambah ketersediaan unsur Zn tanah akibat asam organik mampu melepaskan ikatan Zn fraksi tanah menjadi sedikit larut, menjadi tersedia untuk tanaman.

\section{Status Hara Trubus dan Serapan Hara}

Kadar hara $\mathrm{N}$ dalam trubus berbeda nyata jika dibandingkan dengan kontrol (tanpa pemupukan) sebesar 0,47\% dengan serapan $\mathrm{N}$ paling rendah yaitu 0,16 gram/tanaman. Rendahnya serapan hara $\mathrm{N}$ merupakan salah satu penyebab rendahnya hasil produksi yang mengakibat pertumbuhan tanaman menjadi terhambat.

Tabel 4. Pengaruh Dosis Pemupukan NPK $+Z n$ terhadap Kadar dan Serapan N, P, K pada Trubus

\begin{tabular}{lcccccc}
\hline Perlakuan & $\begin{array}{c}\mathrm{N} \\
(\%)\end{array}$ & $\begin{array}{c}\text { Serapan } \\
(\mathrm{gr} / \\
\text { tanaman) }\end{array}$ & $\begin{array}{c}\mathrm{P} \\
(\%)\end{array}$ & $\begin{array}{c}\text { Serapan } \\
(\mathrm{gr} / \\
\text { tanaman) }\end{array}$ & $\begin{array}{c}\mathrm{K} \\
(\%)\end{array}$ & $\begin{array}{c}\text { Serapan } \\
(\mathrm{gr} / \\
\text { tanaman) }\end{array}$ \\
\hline Kontrol & $0,47 \mathrm{~b}$ & $0,16 \mathrm{~b}$ & $0,12 \mathrm{e}$ & $0,04 \mathrm{~d}$ & $0,88 \mathrm{f}$ & $0,30 \mathrm{~d}$ \\
$\mathrm{NPK}$ & $0,54 \mathrm{a}$ & $0,25 \mathrm{a}$ & $0,15 \mathrm{c}$ & $0,07 \mathrm{c}$ & $1,14 \mathrm{~b}$ & $0,53 \mathrm{bc}$ \\
$\mathrm{NPK}+0.25 \% \mathrm{Zn}$ & $0,55 \mathrm{a}$ & $0,25 \mathrm{a}$ & $0,14 \mathrm{~d}$ & $0,07 \mathrm{c}$ & $1,21 \mathrm{a}$ & $0,55 \mathrm{abc}$ \\
$\mathrm{NPK}+0.50 \% \mathrm{Zn}$ & $0,56 \mathrm{a}$ & $0,29 \mathrm{a}$ & $0,14 \mathrm{~d}$ & $0,07 \mathrm{c}$ & $1,02 \mathrm{e}$ & $0,52 \mathrm{bc}$ \\
$\mathrm{NPK}+0.75 \% \mathrm{Zn}$ & $0,58 \mathrm{a}$ & $0,31 \mathrm{a}$ & $0,19 \mathrm{a}$ & $0,10 \mathrm{ab}$ & $1,06 \mathrm{~d}$ & $0,55 \mathrm{abc}$ \\
$\mathrm{NPK}+1 \% \mathrm{Zn}$ & $0,56 \mathrm{a}$ & $0,29 \mathrm{a}$ & $0,15 \mathrm{c}$ & $0,08 \mathrm{c}$ & $1,23 \mathrm{a}$ & $0,63 \mathrm{ab}$ \\
$\mathrm{NPK}+1.25 \% \mathrm{Zn}$ & $0,55 \mathrm{a}$ & $0,25 \mathrm{a}$ & $0,16 \mathrm{~b}$ & $0,07 \mathrm{c}$ & $1,05 \mathrm{~d}$ & $0,48 \mathrm{c}$ \\
$\mathrm{NPK}+1.50 \% \mathrm{Zn}$ & $0,55 \mathrm{a}$ & $0,31 \mathrm{a}$ & $0,15 \mathrm{c}$ & $0,08 \mathrm{bc}$ & $1,00 \mathrm{e}$ & $0,55 \mathrm{abc}$ \\
$\mathrm{NPK}+1.75 \% \mathrm{Zn}$ & $0,55 \mathrm{a}$ & $0,31 \mathrm{a}$ & $0,19 \mathrm{a}$ & $0,11 \mathrm{a}$ & $1,10 \mathrm{c}$ & $0,60 \mathrm{ab}$ \\
$\mathrm{NPK}+2 \% \mathrm{Zn}$ & $0,56 \mathrm{a}$ & $0,30 \mathrm{a}$ & $0,15 \mathrm{c}$ & $0,08 \mathrm{c}$ & $1,22 \mathrm{a}$ & $0,66 \mathrm{a}$ \\
\hline
\end{tabular}

Keterangan: Angka yang diikuti oleh huruf yang sama menunjukkan hasil tidak berbeda nyata antar perlakuan dengan uji DMRT 5\%.

Kadar hara P pada trubus berbeda nyata jika dibandingkan dengan kontrol (tanpa pemupukan) sebesar 0,12\%, yang dipupuk Urea 200 $\mathrm{kg} /$ ha dan NPK sebesar 0,15\%, sedang yang dipupuk dengan tambahan 1,75\% Zn meningkat sebesar 0,19\%. Unsur P berfungsi sebagai komponen enzim dan protein, dalam metabolisme sebagai pembentuk biji dan buah. Selain itu ketersediaan $\mathrm{P}$ yang cukup pada periode awal pertumbuhan akan berpengaruh terhadap fase primordia dan pembentukan bagian reproduktif tanaman.

Kadar hara K dalam trubus berbeda nyata 
jika dibandingkan dengan kontrol (tanpa pemupukan) sebesar 0,88\% sedangkan ada penambahan pupuk Urea $200 \mathrm{~kg} / \mathrm{ha}$ dan NPK $300 \mathrm{~kg} /$ ha memiliki kandungan 1,14\%. Data tersebut menunjukkan bahwa pemupukan tersebut efektif meningkatkan kadar kalium tanaman. Salah satu fungsi hara $\mathrm{K}$ dalam tanaman ialah diperlukan dalam pengubahan energi matahari menjadi tenaga kimia (ATP, ADP) di samping berfungsi mentranslokasi karbohidrat dari daun ke akar (Hartt dalam Mengel dan Kirkby, 1978).

Tabel 5. Pengaruh Dosis Pemupukan NPK $+Z n$ terhadap Serapan Zn dan Produksi Padi

\begin{tabular}{lcc}
\hline \multicolumn{1}{r}{ Perlakuan } & $\mathrm{Zn}(\mathrm{mg} / \mathrm{kg})$ & Serapan (gr/tanaman) \\
\hline Kontrol & $47,85 \mathrm{c}$ & $1,63 \mathrm{c}$ \\
$\mathrm{NPK}$ & $55,77 \mathrm{bc}$ & $2,62 \mathrm{~b}$ \\
$\mathrm{NPK}+0.25 \% \mathrm{Zn}$ & $57,12 \mathrm{abc}$ & $2,61 \mathrm{~b}$ \\
$\mathrm{NPK}+0.50 \% \mathrm{Zn}$ & $58,92 \mathrm{abc}$ & $3,02 \mathrm{ab}$ \\
$\mathrm{NPK}+0.75 \% \mathrm{Zn}$ & $67,12 \mathrm{ab}$ & $3,52 \mathrm{ab}$ \\
$\mathrm{NPK}+1 \% \mathrm{Zn}$ & $61,63 \mathrm{ab}$ & $3,16 \mathrm{ab}$ \\
$\mathrm{NPK}+1.25 \% \mathrm{Zn}$ & $57,67 \mathrm{abc}$ & $2,65 \mathrm{~b}$ \\
$\mathrm{NPK}+1.50 \% \mathrm{Zn}$ & $68,41 \mathrm{a}$ & $3,81 \mathrm{a}$ \\
$\mathrm{NPK}+1.75 \% \mathrm{Zn}$ & $68,38 \mathrm{a}$ & $3,77 \mathrm{a}$ \\
$\mathrm{NPK}+2 \% \mathrm{Zn}$ & $63,14 \mathrm{ab}$ & $3,46 \mathrm{ab}$ \\
\hline
\end{tabular}

Keterangan: Angka yang diikuti oleh huruf yang sama menunjukkan hasil tidak berbeda nyata antar perlakuan dengan uji DMRT 5\%.

Kandungan $\mathrm{Zn}$ tanaman berbeda nyata antara kontrol dengan perlakuan penambahan 0,75\% Zn hingga 2\% yakni mampu meningkatan kadar hara $\mathrm{Zn}$ dalam trubus sebesar 57,67 mg/kg hingga $68,41 \mathrm{mg} / \mathrm{kg}$. Penambahan berbagai dosis kadar $\mathrm{Zn}$ ternyata tidak berpengaruh signifikan antar perlakuan penambahan Zn. Terdapat peningkatan kadar $\mathrm{Zn}$ trubus seiring dengan peningkatan dosis dari konsentrasi $0,25 \% \mathrm{Zn}$ hingga $0,75 \% \mathrm{Zn}$ dan meningkat tajam saat penambahan 1,5\% Zn hingga 1,75\% Zn. Begitu pula terjadinya peningkatan serapan $\mathrm{Zn}$ dari penambahan pupuk, sebesar 2,61 mg/tanaman hingga 3,81 mg/tanaman yang mampu meningkatan baik bobot kering total tanaman mau- pun produksinya dibandingkan pada tanaman kontrol. Hal ini menunjukan bahwa pertumbuhan dan serapan $\mathrm{Zn}$ tanaman padi menjadi terhambat disebabkan kekurangan asupan unsur hara salah satunya unsur Zn sehingga berdampak pada jumlah produksi yang dihasilkan rendah tercermin pada tanaman kontrol, dan sebaliknya dengan penambahan kadar 1,75\% Zn serapan maupun hasil produksinya dapat meningkat.

\section{Produktivitas Padi}

Perlakuan pemupukan NPK + Zn dengan dosis beragam memberikan nilai yang berbeda nyata dan lebih tinggi dibandingkan kontrol, produksi tertinggi sebesar 9,96 ton/ha pada dosis penambahan $1,75 \% \mathrm{Zn}$. Produksi gabah kering panen (GKP) meningkat dengan pemakaian pupuk NPK + Zn dibandingkan tanpa pemupukan. Peningkatan dosis pupuk NPK $+\mathrm{Zn}$ tidak diikuti pula dengan peningkatan jumlah produksi. Pada perlakuan penambahan $1 \%$ dan 1,25\% Zn produksi padi agak turun diakibatkan terserang beluk pada beberapa malainya.

Tabel 6. Pengaruh Dosis Pemupukan NPK +Zn terhadap Produksi Padi

\begin{tabular}{lc}
\hline \multicolumn{1}{c}{ Perlakuan } & Produksi Padi (ton/ha) \\
\hline Kontrol & $3,76 \mathrm{~b}$ \\
$\mathrm{NPK}$ & $7,35 \mathrm{a}$ \\
$\mathrm{NPK}+0.25 \% \mathrm{Zn}$ & $8,54 \mathrm{a}$ \\
$\mathrm{NPK}+0.50 \% \mathrm{Zn}$ & $9,16 \mathrm{a}$ \\
$\mathrm{NPK}+0.75 \% \mathrm{Zn}$ & $9,37 \mathrm{a}$ \\
$\mathrm{NPK}+1 \% \mathrm{Zn}$ & $8,60 \mathrm{a}$ \\
$\mathrm{NPK}+1.25 \% \mathrm{Zn}$ & $7,46 \mathrm{a}$ \\
$\mathrm{NPK}+1.50 \% \mathrm{Zn}$ & $9,39 \mathrm{a}$ \\
$\mathrm{NPK}+1.75 \% \mathrm{Zn}$ & $9,96 \mathrm{a}$ \\
$\mathrm{NPK}+2 \% \mathrm{Zn}$ & $8,77 \mathrm{a}$ \\
\hline
\end{tabular}

Keterangan: Angka yang diikuti oleh huruf yang sama menunjukkan hasil tidak berbeda nyata antar perlakuan dengan uji DMRT 5\%.

Penggunaan dosis pupuk organik $500 \mathrm{~kg} /$ ha, $300 \mathrm{~kg} /$ ha pupuk NPK dan $200 \mathrm{~kg} /$ ha Urea mampu meningkatkan produksi tanaman padi 
sebesar 7,35 ton/ha atau meningkat 95,47\% dibandingkan dengan kontrol (3,76 ton/ha), sedangkan penggunaan pupuk NPK $+0,25 \% \mathrm{Zn}$ mampu meningkatkan produksi tanaman padi sebesar 127,1 \% dibandingkan dengan kontrol, dan meningkat $164,9 \%$ saat penambahan kadar 1,75\% Zn. Sehingga penggunaan pupuk Zn efektif meningkatkan produksi padi jika dibandingkan tanpa pemupukan.

Hasil percobaan menunjukan kandungan Zn tanaman berbeda nyata antara kontrol dengan perlakuan penambahan $0,75 \%$ hingga $2 \% \mathrm{Zn}$ yakni mampu meningkatan kadar hara $\mathrm{Zn}$ dalam trubus sebesar $67,12 \%$ hingga $68,71 \%$. Penambahan berbagai dosis kadar Zn ternyata tidak berpengaruh signifikan pada antar perlakuan penambahan Zn. Hal ini menunjukan bahwa pertumbuhan dan serapan $\mathrm{Zn}$ tanaman padi menjadi terhambat disebabkan kekurangan asupan unsur hara salah satunya unsur Zn sehingga berdampak pada jumlah produksi yang dihasilkan rendah tercermin pada tanaman kontrol, dan sebaliknya dengan penambahan kadar $1,75 \% \mathrm{Zn}$ serapan maupun hasil produksinya dapat meningkat.

\section{SIMPULAN}

Pemupukan dengan dosis NPK $300 \mathrm{~kg} / \mathrm{ha}$ $+1,75 \% \mathrm{Zn}$ optimum meningkatkan pertumbuhan, produksi, dan serapan hara padi sawah di Inceptisol Kebumen. Ada kecenderungan pada takaran $1.75 \%$ Zn memberikan hasil tertinggi yaitu sebesar 9,96 ton/ha dengan serapan hara sebesar 3,77 gram/tanaman dibandingkan dengan kontrol yang memiliki produksi 3,76 ton/ha dan serapan Zn paling rendah yaitu 1,63 gram/ tanaman.

\section{DAFTAR PUSTAKA}

Al-Jabri, M., M. Soepartini, dan D. Ardi S. 1990. Status hara Zn dan pemupukannya di lahan sawah. hlm. 427-464. Prosiding Lokakarya Nasional Efisiensi Penggunaan Pupuk V, Cisarua, 12-13 November 1990. Pusat Penelitian Tanah dan Agroklimat, Bogor.

Barker, V Allen and D.J. Pilbean. 2007. Handbook of Plant Nutrition. Taylor and Francis. London. New York.

Juliati, S. 2008. Pengaruh Pemberian Zn dan P terhadap Pertumbuhan Bibit Jeruk Varietas Japanese Citroen pada Tanah Inceptisol. Jurnal Hort. 18(4): 409-419.

IRRI. 2014. Zinc InSoil.<http://www.knowledgebank.irri.org/ ericeproduction/zinc.pdf>. Diakses 12 Juli 2014.

Ponnemperuma, F.N. 1976. Specific Soil Chemical Characteristics for Rice Production in Asia. IRRI Research Paper Series No. 2. The International Rice Research Institute, Manila, Philippines.

Setiobudi D., H. Sembiring. 2008. Tanggap Pertumbuhan dan Hasil Padi Tipe Baru Terhadap Pupuk Makro dan Mikro Pada Spesifik Jenis Tanah. Seminar Nasional Padi. Balai Besar Penelitian Tanaman Padi. Jawa Barat.

Setyamidjaja D. 1996. Pupuk dan Pemupukan. Simplex. Jakarta. Sims, J.T. 1986. Soil pH Effects on the Distribution and Plant Availability of Manganese, Copper and Zinc. Soil. Sci. Amer. J. 50: 367-373.

Suhariyono Gatot dan Y. Menry. 2005. Analisis Karakteristik Unsur-Unsur dalam Tanah di Berbagai Lokasi dengan Menggunakan XRF. Batan. Prosiding PPI - PDIPTN 2005 Puslitbang Teknologi Maju BATAN. Yogyakarta.

Welch, R.M. 1999. Importance of Seed Mineral Nutrient Reserves in Crop Growth.pp.205-206. In Z. Rengel (editor). Mineral Nutrition of Crops. Food Product Press. New York.

Yulnafatmawita, Sandra Prima, Aprisal, Nurhajari Hakim. 2014. Pengaruh Unsur Mikro Terhadap Peningkatan Hasil Padi Di Sawah Intensifikasi yang Diberi Pupuk Organik Titonia Plus. Thesis. Program Studi Imu tanah Fakultas Pertanian Universitas Lampung. Lampung. 